\title{
BARIUM EXTRACTION POTENTIAL BY MUSTARD, SUNFLOWER AND CASTOR BEAN
}

\author{
Aline Renée Coscione*; Ronaldo Severiano Berton \\ Instituto Agronômico - Centro de P\&D de Solos e Recursos Ambientais - C.P. 13020-902 - Campinas, SP - Brasil. \\ *Corresponding author <aline@iac.sp.gov.br>
}

\begin{abstract}
Barium salts are used extensively for industrial purposes, generating residues that, if not appropriately disposed, can increase soil Ba content. The aim of the present work was to evaluate $\mathrm{Ba}$ extraction potential of mustard (Brassica juncea Czern.), sunflower (Helianthus annuus L.), and castor bean (Ricinus communis L.), grown in a soil artificially contaminated with increasing Ba additions. A greenhouse experiment was carried out by adding $\mathrm{BaSO}_{4}$ to a Rhodic Hapludox sample, at the 0, 150 and $300 \mathrm{mg} \mathrm{kg}^{-1}$ rates. After harvesting, the pot soil material was also analyzed for exchangeable Ba by $\mathrm{CaCl}_{2}$ extraction and by an ion exchange resin method. None of the plant species tested presented toxicity symptoms, decreased nutrient accumulation or decreased dry matter production in response to $\mathrm{Ba}$ treatments. The accumulation of $\mathrm{Ba}$, in decreasing capacity was: sunflower $>$ mustard $>$ castor bean. The largest accumulation was with sunflower at $300 \mathrm{mg} \mathrm{kg}^{-1}$ of Ba added to the soil. When evaluated by the transference factor, none of the species tested was an efficient $\mathrm{Ba}$ accumulator, up to 47 days after emergence. The ion exchange resin method was not adequate to evaluate Ba availability to these plants.
\end{abstract}

Key words: toxicity, phytoextraction, fransference factor, ion exchange resin, exchangeable Ba

\section{POTENCIAL DE EXTRAÇÃO DE BÁRIO POR MOSTARDA, GIRASSOL E MAMONA}

\begin{abstract}
RESUMO: Sais de bário (Ba) são freqüentemente utilizados em diversas atividades industriais gerando resíduos que, se não dispostos adequadamente, podem elevar os teores desse metal no solo. Neste estudo, avaliou-se o potencial de extração de bário das espécies mostarda (Brassica juncea Czern.), girassol (Helianthus annuus L.) e mamona (Ricinus communis L.) com a finalidade de serem empregadas na fitorremediação de solos contaminados com esse elemento. Após o corte da parte aérea, o solo foi amostrado para determinação do $\mathrm{Ba}$ solúvel em $\mathrm{CaCl}_{2}$ e $\mathrm{Ba}$ trocável pelo método da resina trocadora de íons. Todas as espécies testadas não apresentaram sintomas de toxidez de $\mathrm{Ba}$ ou diminuição na produção da massa seca da parte aérea. Também não foram observadas alterações significativas na absorção de nutrientes pelas três espécies. Com relação à capacidade de extração de Ba do solo, as espécies se comportaram na seguinte ordem decrescente de acúmulo desse elemento na parte aérea: girassol $>$ mostarda $>$ mamona. Nenhuma das três espécies mostrou-se eficiente em extrair Ba do solo, até aos 47 dias após a germinação. O método da resina trocadora de íons não foi eficiente em indicar as quantidades fitodisponíveis de Ba presentes no solo.

Palavras-chave: toxidez, fitoextração, fator de transferência, resina de troca iônica, bário trocável
\end{abstract}

\section{INTRODUCTION}

Barium is an earth alkaline metal with similar geochemistry to calcium. Although often highly insoluble in water and mineral acids the Ba salts are extensively used for industrial purposes. Barium salts used on domestic utensils can lead to its accumulation in urban residues, such as sewage sludge industrial residues that include materials such as petroleum perforation mud. For both residues, the final disposition is commonly the soil (Ippolito \& Barbarick, 2006; Brewer et al., 2004). Ba salts solubilization and their cation release can occur under specific conditions of $\mathrm{pH}$, in absence of oxygen, or due to microbial action, (Baldi et al., 1996; Carbonell et al., 1999; Davidson et al., 2005; Phillips et al., 1998; Ghode et al., 1995).

A large number of plants has small quantities of $\mathrm{Ba}\left(4 \mathrm{a} 50 \mathrm{mg} \mathrm{kg}^{-1}\right)$ in their tissues. When larger amounts are accumulated this element can be toxic inhibiting plant growth (Chaudhry et al., 1977; Llugany et al., 2000; Kuperman et al., 2006). Also, in animals and men, the ingestion of $\mathrm{Ba}$ in soluble forms is highly toxic. Thus, the monitoring of $\mathrm{Ba}$ 
accumulation in soil and water has deserved attention in local and international environmental legislation (Cetesb, 2005).

Phytoextraction, one of the phytoremediation techniques, consists of the use of metal-accumulating plants to remove undesirable metals from a contaminated soil by the harvesting and remotion of their shoots. This alternative is promising since it could reduce costs and is more environmental friendly than others. Mustard (Brassica juncea Czern.) has been used successfully to remove lead from soils (Blaylock et al., 1997), and sunflower (Helianthus annuus L.) has been shown also to act as a phytoaccumulating species. On the other hand, castor bean plant (Ricinus communis L.) is a robust grower, with high biomass production and hence with potential as a phytoaccumulator. The aim of the present work was to evaluate $\mathrm{Ba}$ extraction from soils for these three species, grown in a soil contaminated with increasing $\mathrm{Ba}$ contents.

\section{MATERIAL AND METHODS}

A greenhouse experiment was carried out from March to May 2004 at Campinas, State of São Paulo, Brazil (22 $53^{\prime} \mathrm{S}$; 47 $03^{\circ} \mathrm{W}$; $674 \mathrm{~m}$ ), to evaluate Ba extraction potential by mustard, sunflower, and castor bean.

Soil sampling and characterization - A surface (0$20 \mathrm{~cm}$ ) sample of a Rhodic Hapludox was used in a greenhouse experiment. It was collected at Campinas, SP, Brazil, and tested for soil fertility (Raij et al., 2001) resulting: $\mathrm{pH}$ in $0.01 \mathrm{M} \mathrm{CaCl}_{2}(1: 2$ soil solution ratio): 6.1; organic matter: $3.7 \mathrm{~g} \mathrm{dm}^{-3}$; $\mathrm{P}$ (resin): $12 \mathrm{mg} \mathrm{dm}^{-3}$; $\mathrm{V}: 89 \%$; and the following attributes in $\mathrm{mmol}_{\mathrm{c}} \mathrm{dm}^{-3}: \mathrm{K}$ : 2.5; Ca: 83; Mg: 31; H+Al: 15; CEC: 131.3. Particle size (Camargo et al., 1986) presented: 537; 173 and $290 \mathrm{~g} \mathrm{~kg}^{-1}$, of clay, silt and sand, respectively. Barium soil background concentration was $27.5 \mathrm{mg} \mathrm{kg}^{-1}$ as determinated by the EPA 3051 method (US EPA, 1995).

Experimental design - The treatments were arranged as a completely randomized design, in a $3 \times 3$ factorial experiment (three species and three Ba rates), with three replications. Air-dried soil samples were sieved trough a 3-mm-mesh screen and portions of $1.65 \mathrm{dm}^{3}$ (equivalent to $2 \mathrm{~kg}$ ) were amended with $\mathrm{Ba}$. The $\mathrm{Ba}$ rates in $\mathrm{mg} \mathrm{kg}^{-1}$ were: 0,150 , and 300 added as $\mathrm{BaSO}_{4}$. These last two rates are equivalent to the levels of alert and intervention in agricultural lands, respectively (Cetesb, 2005). After the contaminant addition, the soil was fertilized (mg per pot) as follows: 500 of $\mathrm{P}$ (simple superphosphate); and a solution prepared with $\mathrm{KCl}$, $\left(\mathrm{NH}_{4}\right)_{2} \mathrm{SO}_{4}, \mathrm{H}_{3} \mathrm{BO}_{4}, \mathrm{ZnSO}_{4}, \mathrm{MnSO}_{4} .3 \mathrm{H}_{2} \mathrm{O}, \mathrm{CuSO}_{4} .5 \mathrm{H}_{2} \mathrm{O}$ and $\mathrm{Na}_{2} \mathrm{MoO}_{4} \cdot 2 \mathrm{H}_{2} \mathrm{O}$ to provide 400 of $\mathrm{K} ; 57$ of $\mathrm{S} ; 50$ of $\mathrm{N}$; 1.5 of $\mathrm{B}$; 4.0 of $\mathrm{Zn} ; 2.0$ of $\mathrm{Mn}$; 0.5 of $\mathrm{Cu}$, and 0.4 of Mo, respectively. Following, the soil was homogenized and transferred to $2 \mathrm{dm}^{3}$ plastic pots. Soil water was monitored daily during the course of the experiment, by weighting the pots and adding deionized water to the soil surface up to $60 \%$ of soil maximum water retention capacity. Maximum water retention capacity was determined previously by weighting the pots before and after the saturated soil had been freely drained for two hours. Each pot received six castor bean, ten mustard or ten sunflower seeds and after seedling emergence, three plants per pot for mustard and two plants per pot were left for castor bean and sunflower. At 7, 14, 21, and 28 days after emergence, a total of $700 \mathrm{mg}$ of $\mathrm{N}$ per pot was added by a solution containing $\mathrm{NH}_{4} \mathrm{NO}_{3}(300 \mathrm{mg}), \mathrm{Ca}\left(\mathrm{NO}_{3}\right)_{2} \cdot 4 \mathrm{H}_{2} \mathrm{O}$ (200 mg), and $\mathrm{Mg}\left(\mathrm{NO}_{3}\right)_{2} \cdot 6 \mathrm{H}_{2} \mathrm{O}(200 \mathrm{mg})$. At 47 days after emergence shoots were harvested.

Analytical determinations - After harvesting the shoots were washed with tap water and oven dried at $60^{\circ} \mathrm{C}$ to constant weights. In sequence, the shoot dry matter yields were determined, ground in a Wiley mill, and submitted to oven digestion (incineration) according to Bataglia et al. (1983) for determination of $\mathrm{P}$, $\mathrm{Mg}, \mathrm{Ca}, \mathrm{K}, \mathrm{Zn}, \mathrm{Mn}, \mathrm{Fe}, \mathrm{Cu}$, and $\mathrm{B}$ by inductively coupled plasma emission spectrometry (ICP-OES). Nitrogen content was determined by a modified Kjeldahl method (Raij et al., 2001).

Soil samples from each pot were analyzed for $\mathrm{Ba}$ using the ion exchange resin method commonly employed for routine soil fertility analysis (Raij et al., 2001) and by extraction with $0.1 \mathrm{~mol} \mathrm{~L}^{-1} \mathrm{CaCl}_{2}$ solution, using a 1:2.5 soil - solution ratio, with ICP-OES determination.

Results for shoots barium concentration and shoots barium accumulation per pot (Table 1) were submitted to orthogonal polynomial regression for evaluation of linear or deviation of linear trends using F test, and shoots dry matter were submitted to average comparison by student $\mathrm{t}$ test (using $\mathrm{s}_{\text {pooled }}$ and four degrees of freedom), both at 5\% significance level (Gomes, 2000; Conagin et al., 2006). In addition, Figures were added in order to show the separation of means and the trends assessed by the statistical analysis.

For orthogonal polynomial regression evaluation of linear trend, considering when no barium was applied to the soil $\left(\mathrm{T}_{\mathrm{o}}\right)$; for $150 \mathrm{mg} \mathrm{kg} \mathrm{m}^{-1} \mathrm{Ba}$ added to the soil $\left(\mathrm{T}_{1}\right)$ and for $300 \mathrm{mg} \mathrm{kg}^{-1}\left(\mathrm{~T}_{2}\right)$, the average of treatments was used to obtain the sum of squares (SS) for the evaluation of linear (l) or deviation of linear (dl) trends by: 
Table 1 - Orthogonal polynomial regression results for barium in the species evaluated.

\begin{tabular}{|c|c|c|c|}
\hline Specie & Sum of Squares & Sum of Squares ${ }_{\text {error }}$ & $\mathrm{F}_{\text {calc }}(1)$ \\
\hline \multicolumn{4}{|c|}{ shoots barium concentration } \\
\hline Sunflower & 43.7 & 1.46 & 29.96 \\
\hline Mustard & 23.2 & 1.83 & 12.68 \\
\hline Castor bean & 0.52 & 1.88 & 0.53 \\
\hline \multicolumn{4}{|c|}{ shoots barium accumulation } \\
\hline Sunflower & $3.7 \times 10-2$ & $1.3 \times 10-3$ & 27.71 \\
\hline Mustard & $8.0 \times 10-4$ & $1.1 \times 10-3$ & 7.96 \\
\hline Castor bean & $9.6 \times 10-5$ & $2.7 \times 10-4$ & 0.35 \\
\hline
\end{tabular}

(1) if $\mathrm{F}_{\text {calc }}>5.99\left(\mathrm{~F}_{1,6,95 \%}\right)$ linear trend is significant.

$S S_{l}=\left[1 T_{2}-1 T_{0}\right]^{2} / 3\left(1^{2}+(-1)^{2}\right)=\left(T_{2}-T_{0}\right)^{2} / 6$

$S S_{d l}=\left[1 T_{2}+1 T_{0}-2 T_{1}\right]^{2} /\left[1^{2}+1^{2}+(-2)^{2}\right] 3=\left(T_{2}+T_{0}-2 T_{1}\right)^{2} / 6$

where the mean of square (MS) will be given by the SS divided by 1 and $\mathrm{F}$ can be calculated as: $\mathrm{F}_{\text {calc }}=\left(\mathrm{MS}_{l}\right.$ or $\left.\mathrm{MS}_{d i}\right) / \mathrm{MS}_{\text {error }}$ and compared to the tabulated values of $\mathrm{F}_{1,6,95 \%}$.

The phytoextraction potential of species was be evaluated by the transference factor $(\mathrm{T})$, defined as the ratio of the contaminant concentration in the plant tissue and its total concentration in the soil (Accioly \& Siqueira, 2000). The desirable values for phytoaccumulating plants are above 1 .

\section{RESULTS AND DISCUSSION}

No toxicity symptoms were observed in shoots for the species tested during the experiment. Ba did not affect the development of the plants since there was no difference between dry matter productions in soil with or without $\mathrm{Ba}$ for each species (Figure 1$)$, when compared using $t$ test $(p<0.05)$. Also based on these results effects on plant growth that might be caused by the sulphate salt can be discarded.

In spite of no effect of Ba toxicity on plant growth was observed, the t test comparisons confirmed that sunflower had a higher dry matter production than castor bean or mustard and that mustard had a higher dry matter production than castor bean. Sunflower dry matter was $161 \%$ and $71 \%$ higher than castor bean and mustard productions, respectively. This higher production could result in a concordant higher accumulation of $\mathrm{Ba}$ by sunflower if the concentrations of $\mathrm{Ba}$ were equal among the species.

For the $\mathrm{N}, \mathrm{P}, \mathrm{Mg}, \mathrm{Ca}, \mathrm{K}, \mathrm{Zn}, \mathrm{Mn}, \mathrm{Fe}, \mathrm{Cu}$ and $\mathrm{B}$ concentrations in the plants tissues (data not tabulated), no differences between treated or not treated plants with $\mathrm{Ba}$ were found, an indication that the addition of $\mathrm{Ba}$ to the soil, at the levels studied, imparted in no change in nutrient accumulation by plants, al-

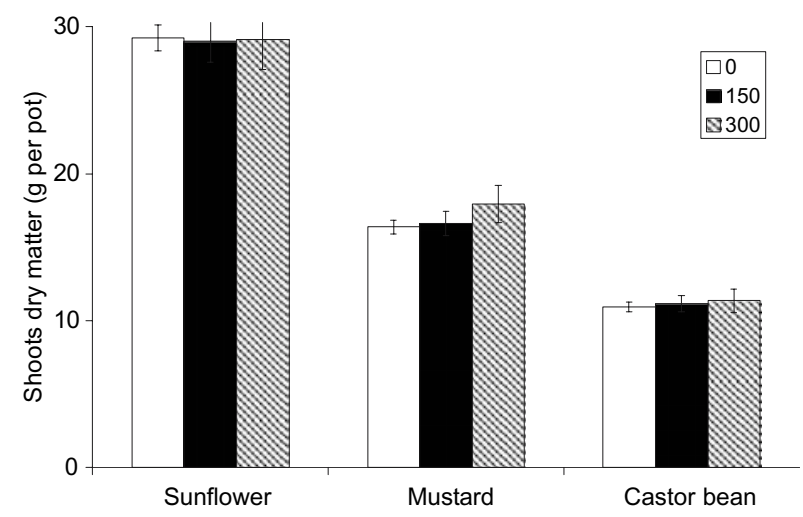

Figure 1 - Effects of increasing Ba applied to the soil $(0,150$ and $300 \mathrm{mg} \mathrm{kg}^{-1}$ ) on average shoot dry weight of three species cultivated for 47 days. Error bars indicate the standard deviation of mean values for each treatment.

though examples of imbalances between $\mathrm{Ca}$ or $\mathrm{K}$ and $\mathrm{Ba}$ or deficiency of $\mathrm{S}$ in the presence of elevated contents of Ba were reported (Chaudry et al., 1997; Llugany et al., 2000).

The analysis by orthogonal polynomial regression, at the significance level adopted, showed a difference among Ba levels for sunflower and mustard, with a linear trend (Figure 2). However, the same trend did not occur for castor bean, with low accumulation occurring in soils treated with Ba (Table 1). No deviation of linearity was observed for the species tested. Thus, the former two are more promising as good phytoaccumulating plants in the remediation of areas contaminated with this metal, as its maximum accumulation was not reached in the present study. The highest concentration of $\mathrm{Ba}$ was obtained for sunflower, with $21.3 \mathrm{mg} \mathrm{kg}^{-1}$, followed by mustard (19.4 $\mathrm{mg} \mathrm{kg}{ }^{-1}$ ), and castor bean (10.6 $\mathrm{mg} \mathrm{kg}^{-1}$ ).

The three plant species evaluated presented distinct behavior under Ba stress (Figure 3). The analysis by orthogonal polynomial regression showed a similar result to that of Barium concentrations in shoots, with differences among Ba levels for sunflower and 
mustard, (a linear trend) and it was not significant for accumulation of barium in castor bean (Table 1). Decreasing capacity of $\mathrm{Ba}$ accumulation was: sunflower $>$ mustard $>$ castor bean. The larger accumulation was in sunflower, at the rate of $300 \mathrm{mg} \mathrm{kg}^{-1}$ of Ba added to the soil. At this contaminant level the sunflower also presented a $\mathrm{Ba}$ content $50 \%$ higher than mustard ac-

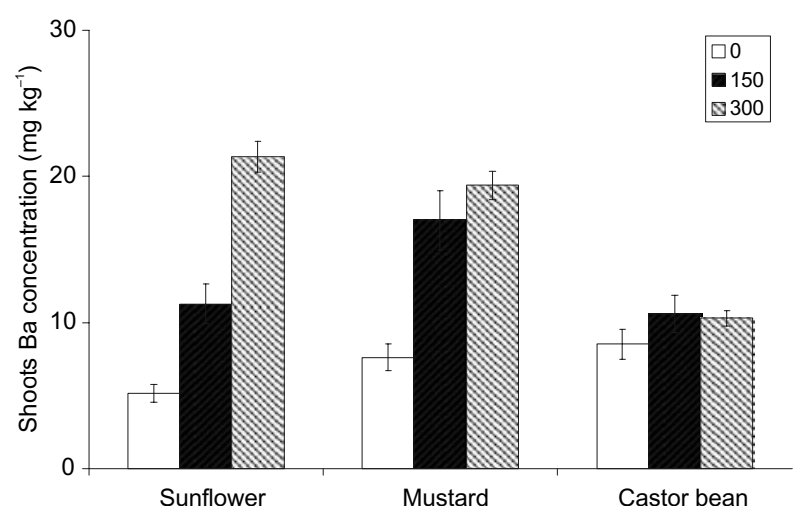

Figure 2 - Effects of increasing Ba applied to the soil on average shoot $\mathrm{Ba}$ concentration of three species cultivated for 47 days.

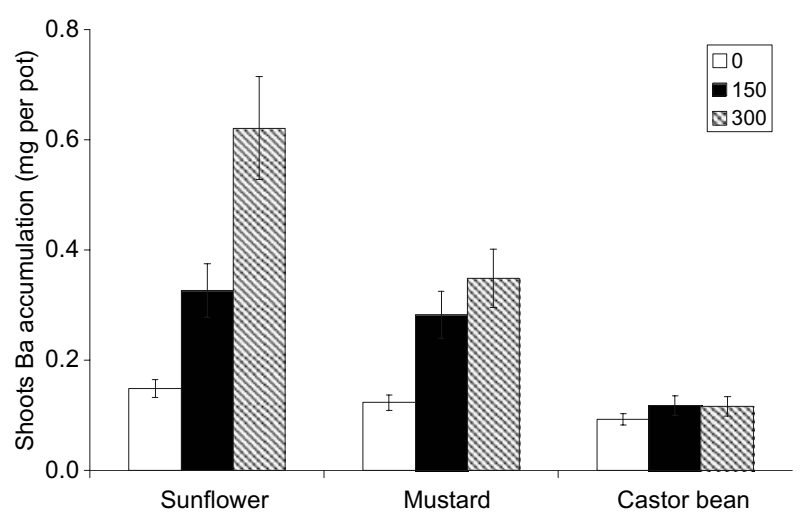

Figure 3 - Effects of increasing $\mathrm{Ba}$ applied to the soil on average $\mathrm{Ba}$ accumulation of three species cultivated for 47 days. cumulated in shoots, in addition to the larger dry matter production. A small response, corresponding to a small increase in Ba shoots accumulation, was observed for castor bean, with the increase of soil contamination.

The highest transference factor $(\mathrm{T})$ values here were $0.071 ; 0.113$, and 0.075 , for castor bean, mustard, and sunflower, respectively, under the application of $150 \mathrm{mg} \mathrm{kg}^{-1}$ of $\mathrm{Ba}$. Those values suggest that the three species evaluated are not suited for $\mathrm{Ba}$ accumulation.

In nature, $\mathrm{Ba}$ content of soils is around 100 to $3000 \mathrm{mg} \mathrm{kg}^{-1}$ (Pais \& Jones Jr., 1998). The Environmental Agency of the State of São Paulo (Cetesb) has recently set $\mathrm{Ba}$ contamination standard values in agricultural lands for São Paulo State, Brazil, adopting 150 and $300 \mathrm{mg} \mathrm{kg}^{-1}$ as alert and intervention values, respectively (Cetesb, 2005). In spite of that, concentrations of $200 \mathrm{mg} \mathrm{kg}^{-1}$ have already been reported as toxic to plants (Pais \& Jones Jr., 1998). Chaudry et al (1977), using 500, 1000 and $2000 \mathrm{mg} \mathrm{kg}^{-1}$ of Ba, added as $\mathrm{Ba}\left(\mathrm{NO}_{3}\right)_{2}$, observed accumulation on shoots and decrease in productions of bush beans and barley. Deleterious effects on root system seem to occur at very low concentrations of free $\mathrm{Ba}$ cation in solutions, as reported for hydroponics (Llugany et al., 2000).

In the present study $\mathrm{Ba}$ was applied to soil as $\mathrm{BaSO}_{4}$ (barite) considering the contamination caused by petroleum perforation mud and the possibility of solubilization from this source as reported elsewhere indicating that $\mathrm{Ba}$ may not be as immobile as expected (Baldi et al., 1996; Carbonell et al., 1999). However, since toxicity and accumulation $\mathrm{Ba}$ is dependent on its availability in the soil, it was also evaluated in the soil material from the pots' experiment.

The $\mathrm{CaCl}_{2}$ extraction, probably corresponding to Ba soluble in soil, presented a small increase in soils treated with barium sulphate (Table 2). Such low val-

Table 2 - Amounts of $\mathrm{Ba}$ extracted from the soil by $\mathrm{CaCl}_{2}$ and ion exchange resin methods, after the harvesting of three plant species cultivated for 47 days. Data presented is the average of three replicates.

\begin{tabular}{|c|c|c|c|}
\hline Ba added & Sunflower & Mustard & Castor bean \\
\hline \multicolumn{4}{|c|}{ mg kg of soil - } \\
\hline \multicolumn{4}{|c|}{$\mathrm{CaCl}_{2}$ extraction } \\
\hline 0 & 1.5 & 0.9 & 1.0 \\
\hline 150 & 2.4 & 1.6 & 1.5 \\
\hline 300 & 3.3 & 1.8 & 1.8 \\
\hline \multicolumn{4}{|c|}{ Ion exchange resin extraction } \\
\hline 0 & 21.4 & 13.8 & 14.8 \\
\hline 150 & 58.8 & 79.4 & 68.6 \\
\hline 300 & 85.6 & 128.0 & 107.2 \\
\hline
\end{tabular}

Sci. Agric. (Piracicaba, Braz.), v.66, n.1, p.59-63, January/February 2009 
ues may explain the lack of symptoms in the plant species testes as well as the low accumulation verified. The evaluation of Ba using the ion exchange resin (Raij et al., 2001), probably corresponding to exchangeable $\mathrm{Ba}$ in soil, lead to surprisingly high contents. The recovery varied from $26 \%$ for sunflower pots, at the 300 $\mathrm{mg} \mathrm{kg} \mathrm{k}^{-1}$ level, to $33 \%$ for castor bean pots under the same dosage while for the $\mathrm{CaCl}_{2}$ extraction, it was $1.0 \%$ and $0.4 \%$, respectively. Even for the soil without $\mathrm{Ba}$ addition high exchangeable values where found, such as 78 to $50 \%$ of the total Ba content $(27.5 \mathrm{mg}$ $\mathrm{kg}^{-1}$ ). Since Ba salts are sparingly soluble, this unusual extraction might be attributed to the "infinite sink" behavior of ion exchangeable resin, which removed $\mathrm{Ba}$ from soil solution thereby promoting $\mathrm{BaSO}_{4}$ dissolution due to the chemical equilibrium. In addition, since $\mathrm{Ba}$ absorbed by the species tested was very low (not more than $0.1 \%$ of the $\mathrm{Ba}$ added) it seems that this method is not adequate to evaluate $\mathrm{Ba}$ availability to plants.

\section{CONCLUSIONS}

According to their extraction capacity of $\mathrm{Ba}$ from the soil, the species can be classified in following order: sunflower $>$ mustard $>$ castor bean. None of the three species studied was efficient as a $\mathrm{Ba}$ accumulator, up to 47 days after emergence. The ion exchange resin method was not suitable in predicting the phytoavailability of Ba present in the soil.

\section{REFERENCES}

ACCIOLY, A.M.A.; SIQUEIRA, J.O. Contaminação química e biorremediação do solo. In: NOVAIS, R.F.; ALVAREZ V, V.H; SCHAEFER, C.E.G.R. (Ed.) Tópicos em ciência do solo. Viçosa: SBCS, 2000. p.299-352.

BALDI, F.; PEPI, M.; BURRINI, D.; KNIEWALD, G.; SCALI, D.; LANCIOTTI, E. Dissolution of Ba from barite in sewage sludges and cultures of Desulfovibrio desulfurican. Applied Environmental Microbiology, v.62, p.2398-2404, 1996.

BATAGLIA, O.C.; FURLANI, A.M.C.; TEIXEIRA, J.P.F ; FURLANI, P.R.; GALLO, J.R. Métodos de análise de plantas. Campinas: Instituto Agronômico, 1983. 48p. (Boletim técnico, 78)

BLAYLOCK, M.J.; SLAT, D.E.; DULSHENKOV, S.; ZAKHAROVA, O.; GUSSMAN, C.; KAPULNIK, Y.; ENSLEY, B.D.; RASKIN, I. Enhanced accumulation of lead in Indian Mustard by soil-applied chelating agent. Environmental Science and Technology, v.31, p.860-865, 1997.

BREWER, E.; STEVENSON, A.G.; HOWE, J.A.;CARROL, J.; SHIMMIELD, G.B. Drill cutting accumulations in the Northern and Central North Sea: a review of environmental interactions and chemical fate. Marine Pollution Bulletin, v.48, p. 1225,2004 .
CAMARGO, O.A.; MONIZ, A.C.; JORGE, J.A.; VALADARES, J.M.A.S. Métodos de análise química e física de solos do Instituto Agronômico. Campinas: Instituto Agronômico, 1986. $94 \mathrm{p}$.

CARBONELL, A.A.; PUBLIDO, R.; DELAUNE, R.R.; PATRICK JR., W.H.J. Soluble Ba in barite and phosphogypsum amended Mississipi River alluvial sediment. Journal of Environmental Quality, v.28, p.316-321, 1999.

CHAUDHRY, F.M.; WALLACE, A.; MUELLER, R.T. Ba toxicity in plants. Communications in Soil Science and Plant Analysis, v.8, p.795-797, 1977.

COMPANHIA DE TECNOLOGIA DE SANEAMENTO AMBIENTAL - CETESB. Relatório de estabelecimento de valores orientadores para solos e águas subterrâneas no Estado de São Paulo. São Paulo: CETESB, 2005. 73 p.

COnAGin, A.; NAGAi, V.; AMBrosio, L.A. Princípios de técnica experimental e análise estatística de experimentos. Campinas: Instituto Agronômico, 2006. Ebook, versão1.

DAVIDSON, C.C.; GIBSON, M.D.; HAMILTON, E.; MACGILLIVRAY, B.H.; REGLINSKI, J.; REBAZAL, E. The long-term environmental of strontium and $\mathrm{Ba}$ released from former mine workings in the granites of the Sunart region of Scotland, UK. Chemosphere, v.58, p.793-798, 2005.

GHODE, R.; MULLEY, R. SARIN, R. Operationally determined chemical speciation of barium and chromium in drilling fluid wastes by sequential extraction. Chemical Speciation and Bioavailability, v.7, p.133-137, 1995.

GOMES, F.P. Curso de estatística experimental. 14 ed. Piracicaba: F.P. Gomes, 2000. 473p

IPPOLITO, J.A.; BARBARICK, K.A. Biossolids affect soil Ba in a dryland wheat ecosystem. Journal of Environmental Quality, v.35, p.2333-2341, 2006.

KUPERMAN, R.G.; CHECKAL, R.T.; SIMINI, M.; PHILLIPS, C.I.; SPEICHER, J.A. BARCLIFT, D.J. Toxicity benchmarks for antimony, $\mathrm{Ba}$ and beryllium determined using reproduction endpoints for Folsomia candida, Eisenia fetida and Enchytraeus crypticus. Environmental Toxicity and Chemistry, v.25, p.754-762, 2006.

LLUGANY, M.; POSCHENRIEDER, C.; BARCELO, J. Assessment of Ba toxicity to bush beans. Archives of Environmental Contamination and Toxicology, v.39, p. 440-444, 2000.

PAIS, I.; JONES JR., J.B. The handbook of trace elements. Boca Raton: St. Lucie Press, 1998. 223p.

PHILLIPS, C.; EVANS, J.; HOM, W.; CLAYTON, J. Long-term changes in sediment $\mathrm{Ba}$ inventories associated with drillingrellates discharges in the Santa Maria basin, California, USA. Journal of Environmental Toxicology, v.17, p.1653-1661, 1998.

RAIJ, B. van.; ANDRADE, J.C.; CANTARELLA, H.; QUAGGIO, J.A. Análise química para avaliação da fertilidade de solos tropicais. Campinas: Instituto Agronômico, 2001. 285p.

UNITED STATES ENVIRONMENTAL PROTECTION AGENCY - US EPA. Test methods for evaluating solid waste: physical/ chemical methods. 3 ed. Washington, DC: U.S. EPA, 1995. (SW-846, Method 3051). Available at: http://www.epa.gov/ epaoswer/hazwaste/test/main.htm. Accessed 12 August 2008.

Received May 02, 2007

Accepted April 16, 2008 